\title{
ROBINSON CRUSOÉ EM FOE: COETZEE LÊ DEFOE COM AS LENTES DO PÓS- COLONIALISMO
}

\author{
Wellington Ricardo Fioruci ${ }^{*}$ \\ Universidade Tecnológica Federal do Paraná \\ Carla Denize Moraes $^{* *}$ \\ Universidade Estadual do Centro-Oeste
}

\begin{abstract}
Resumo: Este estudo consiste na análise de dois importantes romances representativos do gênero narrativa de viagem, a saber, Robinson Crusoé (1719) e Foe (1986), cujos autores, respectivamente Daniel Defoe, no século XVIII, e John Maxwell Coetzee, no século XX, dialogam também ao escreverem na língua de Shakespeare. Partindo desses cruzamentos, busca-se estabelecer, através do comparativismo literário, as relações históricas e textuais entre suas respectivas obras. O romance Foe aparece como uma releitura contemporânea do gênero relatos de viagem, o qual já havia sido desenvolvido em Robinson Crusoé, romance precursor desta categoria temática. Coetzee retoma o clássico tecendo reflexões a respeito do contexto colonialista em que Defoe escrevia. Desse modo, Coetzee lança um novo olhar para o tema sob o enfoque do pós-colonialismo. Tal perspectiva reflete no modo de escritura do texto, de forma que o gênero, reflexo da imagem de uma época, acaba sendo reconstruído, de acordo com a perspectiva pós-moderna.
\end{abstract}

Palavras-chave: Robinson Crusoé. Foe. Colonialismo. Pós-colonialismo. Pós-modernismo.

\section{Introdução}

Esta análise pretende realizar um estudo comparado entre romances que têm em

\section{(c) (i) $(9)$}

BY NC ND Esta obra está licenciada sob uma Licença Creative Commons.

\footnotetext{
* Possui graduação (1997), mestrado (2002) e doutorado (2007) em Letras pela Universidade Estadual Paulista Júlio de Mesquita Filho (UNESP-Assis) na área de Literatura Comparada. Concluiu estágio de pósdoutoramento na UFRGS em 2015 e é professor no curso de Letras da Universidade Tecnológica Federal do Paraná, campus Pato Branco. Tem experiência na área de Letras, com ênfase em Literatura Comparada, atuando principalmente nos seguintes temas: cinema, pós-modernismo, literatura comparada, teoria literária, literatura hispano-americana e literatura brasileira. Faz parte do Grupo de Pesquisa Narrativas Estrangeiras Modernas da Unesp, câmpus de Assis e do Grupo de Pesquisa GEPEL da UTFPR - câmpus Pato Branco. E-mail: tonfiorucci@hotmail.com.

** Mestranda do Programa de Pós-Graduação em Letras da Universidade Estadual do Centro-Oeste, (UNICENTRO). Possui graduação em Letras Português-Inglês pela Universidade Tecnológica Federal do Paraná (UTFPR), Campus de Pato Branco. Atualmente, trabalha como professora de Língua Portuguesa, no Colégio SESI, em Francisco Beltrão - PR. E-mail: carla.moraes0581@gmail.com.
}

Anu. Lit., Florianópolis, v. 20, n. 1, p. 53-73, 2015. ISSNe 2175-7917 
comum o tema da viagem, leitmotiv cuja origem está arraigada à própria história do romance. No âmbito dos estudos literários, o Comparatismo, ou simplesmente a Literatura Comparada, mostra amiúde a relação de influência exercida entre autores de diferentes épocas e culturas, pois, de acordo com os vários pensadores que construíram as bases desta teoria, o comparatismo tem: "a literatura geral como objetivo, [e] impõe-se ser a sua teoria efetivamente validada pela experiência literária universal: ela deve ultrapassar 'nossas tradições culturais' e considerar paradigmas e valores culturais pertencentes a outras culturas e literaturas". (NITRINI, 2000, p. 55).

O pensamento citado está embasado em uma visão já bastante contemporânea, do teórico Adrian Marino, discípulo de Etiemble, e demonstra que o aspecto primordial da trajetória desses estudos são os limites de sua abrangência, ao ponto de a professora Sandra Nitrini nomear a Literatura Comparada de "disciplina indisciplinada" (NITRINI, 2000, p. 117). No entanto, é possível entender que a história literária comparatista debruça-se sobre o incessante diálogo entre os textos e as relações de sentido que se estabelecem entre eles (NITRINI, 2000, p. 125).

A partir dessas reflexões, dois aspectos podem ser ressaltados na leitura empreendida pelo presente estudo, sendo um deles a compreensão de que a obra de partida, o romance de Defoe, será lida e relida, desconstruída e reconstruída no interior do romance de Coetzee e, o outro, a importância que se dará aos elementos estéticos e estilísticos que compõem cada romance em sua particularidade. Pode-se dizer que toda leitura, seja de um autor por outro, ou de uma época por outra, é também uma releitura ou uma atualização dos sentidos do texto recuperado pela voz do presente histórico, o que nos leva ao diálogo entre os dois romances que constituem a base deste estudo, bem como o diálogo entre seus autores.

O escritor sul-africano John Maxwell Coetzee, ainda pouco conhecido entre os brasileiros, vem ganhando destaque por seus romances, que trazem consigo questionamentos importantes do ponto de vista social, histórico e existencial. Sua prosa traz à tona os embaraços pelos quais o processo de criação passa quando, por meio de sua linguagem, procura revisitar crítica e criativamente o passado e, mutatis mutandis, a construção da memória, de modo que em muitas de suas proposições problematiza-se a relação entre dominantes e dominados.

Por outro lado, Coetzee coloca no mesmo plano discursivo questões antitéticas, sublinhadas por Fernando de Lima Paulo (2003), mostrando-se pragmáticas e subversivas ao mesmo tempo. Um exemplo é a postura crítica do romancista em relação à dominação quando 
discute o contexto histórico-político da África do Sul. Coetzee coloca os problemas políticos e históricos de sua terra natal ora como centrais, ora como marginais, fato que o torna um escritor de difícil caracterização e, por conseguinte, aguça o olhar da crítica sobre sua produção.

Neste estudo, voltaremos os olhares para uma de suas obras mais instigantes, Foe (1986), que foi escrita à maneira de uma releitura ou mesmo reinvenção do texto que é considerado por muitos críticos como a primeira obra do romance inglês, Robinson Crusoé (1719), do autor Daniel Defoe. Nesse sentido, o trabalho do escritor sul-africano: "tem sido analisado amiúde como um exemplo de metaficção pós-moderna ou pós-colonial. A primeira, [...] um texto que se debruça sobre si mesmo e desfaz-se das pretensões de revelar a verdade; a segunda, uma postura política, subversiva ao cânone europeu". (PAULO, 2003, p. 28). Coetzee, ao resgatar o clássico, toca na questão da ficção em si, desconstruindo o processo de escrita ficcional e discutindo sua relevância enquanto discurso, ao passo que traz à luz questões de cunho ético e político, cuja discussão não seria possível no século XVIII, época em que foi escrito o romance Robinson Crusoé (originalmente publicado como The life and adventures of Robinson Crusoe), o qual lhe serviu de matéria-prima. Isso se dá devido ao fato de que é necessário um afastamento temporal para que se consiga discutir perspectivas tão arraigadas ao seu tempo, ou seja, foi preciso anos de mudanças históricas até se chegar ao momento em que colonizadores teriam seu poder ideológico questionado por aqueles que, em tempos pretéritos, foram colonizados por eles.

Com efeito, Bonnici em seu livro O Pós-Colonialismo e a Literatura (2000), ao fazer menção ao estudo de Ashcroft, chama a atenção para as estratégias de reescrita utilizadas por autores da pós-modernidade, que empregam: "a retomada de obras literárias do cânone ... para a reestruturação das realidades européias em termos pós-coloniais. A finalidade não é a reversão da ordem hierárquica, mas interrogar os pressupostos filosóficos sobre os quais tal ordem estava baseada." (ASHCROFT, 1991, apud BONNICI, 2000, p. 24). Diante do exposto, pode-se afirmar que Coetzee, em Foe, atualiza os sentidos do clássico, lançando uma nova luz sobre a tradição, bem ao gosto da pós-modernidade.

Ao realizar um estudo comparado entre narrativas de viagem escritas em épocas distintas, acredita-se que é possível determinar as influências do clássico sobre o contemporâneo, demonstrando, assim, a presença da intertextualidade entre as obras, bem como delinear o caráter pós-moderno presente em John M. Coetzee, no que diz respeito à renovação do gênero, ao parodiar a obra clássica de Daniel Defoe, Robinson Crusoé. Ao 
reescrever o clássico, à luz de sua época, Coetzee desvela as condições históricas em que cada um dos romances está inserido, fator que os levou a se desenvolverem de maneira distinta, apesar de apresentarem analogias entre si. Tal historicidade está permeada, em ambos os textos, de uma intencionalidade subjetiva, visto que cada autor procura discutir, mesmo que de forma não explícita, a problemática social e política vivenciada por cada um.

Assim, ao se contemplar o caráter histórico por trás da arquitetura da obra, percebese que a visão da realidade corrente reflete-se na escrita do romance, de forma que o texto nasce impregnado pelas experiências do autor e, consequentemente, expõe questões históricas e sociais do seu tempo. Em Robinson Crusoé, particularmente, fica expressa a questão da religião. É interessante destacar que Daniel Defoe era um inglês protestante e, portanto, sua obra apresenta questões relacionadas à ideologia do protestantismo e da burguesia (COSTA LIMA, 2009). Vale adiantar que o próprio Robinson Crusoé é filho de uma família pertencente à classe média, em ascensão na época. Defoe insere inúmeras vezes em sua narrativa traços de sua inclinação religiosa e, em alguns momentos, tem-se a impressão de estar-se diante de uma pregação religiosa, que não aparece gratuitamente no texto, ao contrário, expõe um dos recursos dos quais os colonizadores lançam mão, dentre tantos outros, colocando a serviço da colonização a imposição da religião aos nativos, sendo estes representados no texto pela figura da personagem Sexta-feira.

O relato de Crusoé, em Defoe, chama a atenção para a postura colonialista e, atrelado a isso, aparecem elementos relacionados ao individualismo. Como destaca Ian Watt sobre Defoe, este "expressou os diversos elementos do individualismo de modo mais completo que qualquer outro escritor antes dele.” (1990, p. 57). De fato, os relatos de viagem apontam para a problematização do indivíduo, que a viagem coloca em contato com o outro, e, dessa maneira, “ajuda a se pensar semelhanças ou diferenças, por comparação, e, consequentemente, ajuda na aceitação [...] não apenas da existência da diferença, mas principalmente ajuda a convivência com tal diferença”. (ESTEVES; ZANOTO, 2010, p. 16).

Os relatos de viagem obtêm destaque na literatura colonial em função do momento histórico que representam, isto é, o período das modernas conquistas imperialistas. No entanto, eles são muito mais antigos do que aqueles produzidos pelos sujeitos escritores da época dos descobrimentos, como o são as narrativas épicas, em que a viagem já exercia papel importante e atrativo, atuando como mote inspirador de obras clássicas, como a Odisseia ou a Ilíada, as quais mantêm em comum com as versões modernas o tema da dominação cultural, na vertente do processo de expansão territorial de povos da antiguidade. 
Merece destaque o fato de que a maioria dos relatos é escrita e narrada por figuras masculinas. Portanto, julga-se importante citar o papel da figura feminina em Coetzee como narradora, atitude esta que revela a intenção autoral de desafiar a "hegemonia da consciência masculina no mito robinsoniano.” (BONNICI, 2000, p. 118). Tal estratégia discursiva remete à ideia de silenciamento ou distorção de vozes embutidos no discurso de Defoe, aqui considerado não apenas em relação à figura feminina de Susan Barton, mas também a Friday, que não tem o benefício da palavra, por ter sua língua cortada.

O texto de Coetzee desconstrói a aparência de uma (suposta) verdade incontestável presente em Defoe, trazendo para a discussão a ordem sob a qual aquela sociedade estava organizada, apontando lacunas deixadas pelo clássico. O escritor sul-africano chama atenção para aquilo que não foi passível de discussão no texto de Defoe e figurou como natural. Dessa maneira, Coetzee leva à reflexão sobre questões sociais relevantes como o comércio de escravos, a marginalização da mulher e a imposição do poder colonizador como questões estruturais e, por isso, não passíveis de questionamentos. Cabe ressaltar, não pretendemos com esse estudo comparado apenas estabelecer semelhanças e diferenças entre as obras, mas sim refletir sobre o quanto há de interferência do clássico sobre o contemporâneo, ou seja, como um discurso consegue dar novo sentido ao outro, ou então, servir como resposta ao outro.

\section{As fronteiras do discurso}

A dicotomia história/ficção é recorrente nos estudos dos textos ao longo do tempo. A professora Núbia J. Hanciau, baseando-se em farta tradição crítico-teórica, questiona em seu ensaio "Confluências entre os discursos histórico e ficcional" (2001) os limites existentes entre história e ficção e se, de fato, existe uma fronteira bem definida entre ambos. Em tese, enquanto a história se ocuparia da realidade factual e defenderia o relato da mais pura verdade, o discurso ficcional, através do contato com o cotidiano de um período histórico, conseguiria desvelar verdades que transcenderiam os fatos e as traduziria em textos que muitas vezes dizem muito mais sobre a realidade de uma época do que a própria história. A complexidade dessa relação, problematizada há muito por estudiosos de ambos os campos discursivos, ou seja, tanto da literatura quanto da história, e não só, certamente não se esgota nessas linhas e tampouco no ensaio de Hanciau, mas enseja um debate fortuito entre os romances em questão.

Seguindo essa reflexão, é possível perceber que em Foe o tema da "verdade", introduzido no discurso através da personagem Susan Barton, traz à discussão as confluências 
existentes entre o discurso histórico e o ficcional, uma vez que ambos se imbricam formando um único discurso que aponta para uma leitura da sociedade de uma época. Segundo Fernando de Lima Paulo (2003), o texto de Coetzee desnuda o processo de escrita em si mesmo e através da metaficção consegue trazer à tona a "discussão da verdade num ambiente intelectual marcado por um profundo ceticismo, como o é o pós-modernismo." (PAULO, 2003, p. 28). Ao discutir a ética na ficção, Coetzee faz saltar aos olhos a questão desta enquanto discurso, uma vez que expõe "os artifícios de sua própria construção" (PAULO, 2003, p. 28). Já em Defoe, Bonnici (2000) chama atenção para o fato de que o interesse que a obra suscita aos críticos de vários períodos não se deve somente à questão da falta de um limite claro entre o que é ficção e o que é realidade, mas, principalmente, à problemática colonialista que o texto, por mais que busque camuflar, não consegue esconder. Ao ler o texto de Defoe com atenção, facilmente se pode perceber o "posicionamento do personagem europeu diante do não-europeu”. (BONNICI, 2000, p. 79).

Se observados os períodos distintos em que foram escritos, evidencia-se a presença da ideologia histórico-política vivenciada pelos autores. Enquanto Defoe retrata a face da sociedade europeia do século XVIII, período em que o tráfico de escravos e a subjugação dos povos colonizados ainda figurava como "estrutural", Coetzee vem representar a mudança de postura em relação a tal ideologia, o então chamado pós-colonialismo, que ressoava pelos continentes no século XX, dando voz ao "outro lado", ou seja, aos povos marginalizados até então. Segundo Linda Hutcheon, este gesto de incluir o discurso periférico na literatura pósmoderna tem o efeito de "transformar o diferente, o off-centro, no veículo para o despertar da consciência estética e até mesmo política.” (HUTCHEON, 1991, p. 103). Essa problemática se discute de formas distintas em ambos os textos, motivado por vários fatores, entre eles destacaremos dois, os quais julgamos pertinentes a essa discussão. O primeiro tem como foco central a figura do escritor, o qual, inserido em um determinado contexto histórico, reflete as influências presentes na conduta social de seu tempo. O segundo trata do olhar crítico com que cada um dos autores olha para sua realidade e, no caso de Coetzee, também para o passado.

No que se refere à orientação da produção literária dos autores, deve ser levado em consideração a recepção de cada período. Ora, no século XVIII, Ian Watt (1990, p. 36) assinala que o público leitor ainda era restrito, afinal, ainda era ínfimo o número de pessoas que possuíam instrução. Somado a isso, havia o fato de que a maioria da população não possuía condições financeiras para adquirir livros, que tinham um alto custo. Por outro lado, a 
classe média ascendente, diante da prosperidade por que passava, passou a ter acesso à literatura (WATT, 1990, p. 43) e foi este público que definiu a produção de muitos autores naquela época, como é o caso de Defoe. Já no século XX, as mudanças em constante ebulição, seja na sociedade, seja nos avanços científicos e tecnológicos, faz com que os romances sejam demandados por um público cada vez maior e mais crítico e isso resulta em uma produção que busca entrar em sintonia com o pensamento vanguardista que já havia se estabelecido anos antes, no período modernista. Desta forma, cabe agora ao autor desvelar os mecanismos que tão bem encobriam as adversidades vividas pelos povos colonizados.

Esse processo de desvelamento se dá através da problematização do discurso ficcional, inserindo questionamentos sobre o quanto de histórico há no romance, ou seja, o quanto a ficção pode revelar sobre a historicidade de seu tempo. Para tal, a literatura contemporânea traz à luz questões que se inscrevem no campo da metaficção, mesclando, segundo Majda Bojić (2008), os discursos histórico e ficcional. Desse modo, percebe-se que a produção literária contemporânea, ao fazer referência ao passado, acaba por reconstruí-lo, uma vez que ela, por si só, não tem a propriedade de determinar "verdades" históricas, embora amiúde pareça comprometer-se a tecer reflexões sobre a ideologia da sociedade de onde se originam os textos canônicos.

Com efeito, a problemática colonialista se faz presente em toda a narrativa de Defoe, porém ela é mais bem percebida graças ao distanciamento temporal que há entre o colonial e o pós-colonial. Através da perspectiva da narrativa contemporânea, compreendida aqui a partir de traços pós-modernos e pós-coloniais, é possível lançar um olhar reflexivo sobre a literatura colonial, o que possibilita que Robinson Crusoé seja agora "relido" criticamente, colocando em evidência as lacunas deixadas por Defoe e seu discurso colonialista.

Percebe-se que em Defoe não há maiores questionamentos quanto à relação com o outro, ou seja, as questões relativas à alteridade são camufladas sob o tom de harmonia de convivência entre os personagens. Essa postura instiga a questionar o tratamento que se dá à alteridade nos textos. Em Defoe, o relacionamento com o outro se revela através da forma como o texto aborda a relação entre o branco europeu e os demais povos. Como estes eram submetidos à imposição de costumes daqueles, em outras palavras, as relações sociais estabelecidas entre os seres sociais. Isso tudo feito de maneira a tornar naturais as questões sociais que estão por trás deste discurso, sem deixar transparecer nenhum tipo de tensão em relação ao que representam de fato. 
Já em Coetzee, a discussão metaficcional revela a intenção contida no discurso ficcional, mostrando que sempre há uma ideologia motivadora do que parece ser aos olhos do leitor uma simples representação artística: “A reflexividade textual dos textos pós-modernos revela as implicações naturalizadas dos textos narrativos (como são, por exemplo, as pressuposições de sua transparência) e exige do leitor que aceite o fato de que a representação também tem suas políticas." (BOJIĆ, 2008, p. 2). O que a autora tenta demonstrar é que em todo texto há a presença de um direcionamento que caminha de acordo com as intencionalidades do autor. Segundo ela, é preciso atentar para o fato de que um texto ficcional é sempre uma construção ideológica: “O que tenta esconder é o caráter de construção; o que se quer fazer passar despercebido é a dimensão política do texto”. (BOJIĆ, 2008, p. 2).

Com efeito, em Robinson Crusoé a relação com o não-europeu reflete a política estabelecida pelo império britânico. Há a presença de uma nova classe de pessoas, que haviam desenvolvido no século XVIII uma postura político-religiosa baseada no individualismo. O texto deixa clara a influência religiosa no enredo, que prega a salvação através do trabalho e da produção de bens materiais, tudo isso guiado pela conduta pautada na racionalidade. $\mathrm{O}$ confronto entre indivíduos de posições "hierarquicamente" distintas revela no texto de Defoe como se dá o tratamento à questão do individual versus o coletivo, mediante os fatores históricos presentes em cada contexto. De fato, no final do século XVII e início do século XVIII o mundo passava por uma transformação social em que estava gradativamente se estabelecendo uma nova ordem política e econômica. Tal ordem sofria as influências de uma "desordenação" necessária, para que enfim uma nova significação fosse dada ao ser econômico.

Para Watt, a base dessa nova ordem social já não estava mais na família, na igreja ou qualquer entidade coletiva, mas sim no indivíduo. Este, segundo o autor, era tido como ser autônomo, responsável pelo seu próprio desenvolvimento e se permitia fazer escolhas que nem sempre iam ao encontro do pensamento coletivo vigente. Esse contexto se refletiu obviamente no campo da literatura, cuja polêmica gerou uma divisão de opiniões entre os escritores da época. Havia aqueles que defendiam a tradição, que está intimamente atrelada à visão de coletivo, e outros que aderiram ao movimento transformador, entre eles Daniel Defoe:

Defoe, cuja posição filosófica tem muito em comum com a dos empiristas ingleses do século XVII, expressou os diversos elementos do individualismo de modo mais completo que qualquer outro escritor antes dele, e sua obra apresenta uma 
demonstração única da relação entre o individualismo em suas muitas formas e o surgimento do romance. (WATT, 1990, p. 57)

Neste sentido, Ian Watt afirma que o personagem Crusoé ilustra de maneira simbólica o "homem econômico" da era do capitalismo industrial. Um homem que, apesar das reflexões sobre o valor do dinheiro enquanto vivia na ilha deserta, revela-se sempre guiado pelo seu empreendedorismo:

\begin{abstract}
Desci um pouco pela encosta desse vale encantador, examinando-o com uma espécie de prazer secreto (embora misturado a outros pensamentos que me atormentavam), ao pensar que tudo isso era meu, que era rei e senhor incontestável de toda essa terra, que dela tinha o direito irrevogável de posse, e que se a conseguisse legitimar publicamente poderia transmiti-la por herança tão bem quanto o feudo de um lorde na Inglaterra. (DEFOE, 2010, p. 108)
\end{abstract}

Já o pós-modernismo e, por conseguinte, a perspectiva pós-colonial nele inserida, carrega consigo uma característica distinta de representação do homem no século XX. A obra de J. M. Coetzee procura representar o senso crítico do homem moderno, especialmente dos povos colonizados, sob a ótica da visão pós-colonialista. Isso se dá na forma da reescrita do cânone, que aparece como uma resposta pós-colonial ao texto colonialista. Por outro lado, Bonnici (2000, p. 104) levanta um questionamento interessante sobre a escrita pós-colonial. Ao dar voz ao povo colonizado, surge um impasse: será possível escrever sobre o colonizado estando envolvido em um contexto pós-colonial? As lacunas deixadas por Defoe em seu texto - assim como as lacunas históricas perdidas no tempo - talvez, partindo desta premissa, não possam ser preenchidas por um escritor branco, representativo de uma elite colonizadora, pelo fato de que a realidade do colonizado pertence somente ao "outro lado", ou seja, àqueles que se encontram à margem. Desse modo, o texto de Coetzee vem revelar que se trata de uma reflexão, de acordo com os pressupostos do pós-modernismo, e não de uma tentativa de dar respostas ou revelar conteúdos capazes de preencher as lacunas deixadas pelo colonialismo.

No romance coetzeeano, a frustração da personagem Susan diante da impotência em contar uma história que não é sua, a história de Friday, reflete os limites naturais que a escrita branca enfrenta ao tentar dar voz a povos marginalizados. Segundo Silva (2000), Susan se dá conta de que pouco conhece sobre a história que pretende escrever face ao silenciamento que encontra nos reais detentores do conhecimento, posto que Cruso morre na viagem ao continente e Friday é mudo. Friday simboliza a história que não pode ser contada, sob o signo de sua língua cortada, que o impossibilita de contar sobre sua vida e, desse modo, seu ponto de vista histórico, a saber, antes da chegada do homem europeu. Tal signo delineia os limites naturais do discurso pós-colonial refletindo sobre até onde se pode chegar ao discutir-se uma 
experiência que não é sua, ou seja, definir onde se encontra a fronteira discursiva entre o colonial e o pós-colonial.

\section{O diálogo narrativo entre Coetzee e Defoe sob o enfoque do pós-colonialismo}

O pós-modernismo, cuja poética inclui em grande medida a vertente pós-colonial por questões ideológicas e estilísticas (HUTCHEON, 1991), traz consigo uma estética que se volta para a interpretação dos textos canônicos e essa interpretação possibilita que se faça uma leitura crítica dos textos coloniais, o que para Bonnici (2000) torna analítica a leitura do conteúdo inserido nos textos canônicos. O intuito não é inverter a ordem hierárquica, mas sim chamar atenção para aquela visão eurocêntrica do século XVIII. Este é o trabalho que as literaturas pós-coloniais procuram realizar, destacando-se a dicotomia império-colônia, conforme observa Bonnici (1998, p. 17) ao inserir na discussão o processo de "descolonização", cuja dialética é explorada amplamente por essas literaturas, de acordo com o crítico.

Assim, para que haja uma escrita pós-colonial, é necessário que haja um processo descolonizador, ou seja, que a escrita dos povos oprimidos se liberte das amarras coloniais e conte sua história. E ainda mais: Bonnici (1998) lembra que é necessário que críticos e leitores também alterem sua perspectiva ao entrar em contato com tais obras. Há, porém, que se levar em conta que o cânone nada mais é do que um produto do poder. Quem estipula o que é um cânone é quem tem a força controladora da ideologia. Assim, a centralidade europeia "cria" determinadas regras, ou seja, estabelece que uma obra, para ser canônica, precisa atender aos critérios estabelecidos pelo bloco dominante, refletindo sua cultura e sua postura social, política e econômica, relegando às outras culturas o estereótipo de inferiores: "Não somente a ligação entre o cânone literário e o poder é um fato indiscutível, mas também sua utilização para fixar a superioridade do colonizador, degradar o 'primitivismo' do colonizado e relegar à periferia qualquer manifestação cultural e literária oriunda da colônia." (BONNICI, 1998, p. 16).

Mas então como subverter essa política tão arraigada? Como subverter essas regras sem radicalismos vanguardistas que só fariam pós-modernistas parecerem loucos aos olhos da tradição? Para que o pós-moderno pudesse se estabelecer com uma autêntica literatura póscolonial, a ação se concentrou, então, "na subversão, ou seja, a resposta ao centro." (BONNICI, 1998, p. 18). Nesse sentido, uma das principais estratégias do pós-colonialismo foi questionar a visão central europeia e, para isso, pós-modernistas adotaram a reinterpretação e a reescrita promovendo, assim, a reflexão sobre o passado, mostrando que é 
possível olhar para ele sob um novo ponto de vista, através de um outro ângulo, ou seja, com o olhar do "outro". Chamar-se-á atenção aqui para a reescrita, que consiste na: "retomada de obras literárias do cânone... para a reestruturação das 'realidades' europeias em termos póscoloniais. A finalidade não é a reversão da ordem hierárquica, mas interrogar os pressupostos filosóficos sobre os quais tal ordem estava baseada." (ASHCROFT, 1991, apud BONNICI, 1998, p. 19, grifo do autor)

A reescrita e a releitura aparecem em muitas obras ditas pós-coloniais, com destaque para aquelas escritas em inglês. Conforme afirma Bonnici (2000, p. 42) a reescrita "consiste na apropriação do texto canônico pelo escritor de alguma ex-colônia européia, consciente de seu papel de mestre no contexto pós-colonial”. Neste sentido, John M. Coetzee se apropria do conteúdo do romance inglês do século XVIII, Robinson Crusoé (1719) dando-lhe nova roupagem. Dessa forma, a reescrita em Foe (1986) aponta como uma resposta ao clássico. Segundo o autor, enquanto Defoe constrói o criativo e dominador Robinson Crusoé, um narrador que representa a figura masculina do branco europeu, o narrador em Coetzee é uma mulher europeia, Susan Barton, a qual é forçosamente impelida à convivência com Cruso (alusão à Crusoé, de Defoe, uma clara supressão do sujeito, de sua identidade, conforme se depreende da falta do "e" final), um homem resignado à sua condição de náufrago, e seu criado Friday, o nativo sem voz.

O texto pós-colonial explora muito bem a questão pertinente à metaficção, recurso pós-moderno por excelência segundo Hutcheon (1991), quando discute os artifícios peculiares à escrita de textos narrativos e como a perspectiva pós-colonialista reelabora e discute a problemática dos povos subjugados, que é velada em Robinson Crusoé. Em Coetzee, a personagem-narradora tem como preocupação maior preservar a memória de náufraga em sua integridade e, em contrapartida, vê-se diante da impossibilidade de realizá-la de fato, trazendo a discussão metaficcional ou metanarrativa para dentro do enredo.

Conforme aponta Bonnici (2000, p. 42), Susan sente necessidade de cumprir duas metas: a primeira é transmitir sua história na ilha como genuína expressão da verdade e a outra é desvendar os mistérios sobre o passado de Friday, que tem sua língua cortada, sem deixar claro por quem, e, por isso, não é capaz de contar a própria história, “de escravidão e opressão.” (BONNICI, 2000, p. 42). Susan Barton vê-se em conflito diante dos fatos que deseja narrar e como irá fazê-lo. Sua intenção em registrar sua história a faz procurar um escritor, Foe, cujo nome faz alusão metaficcional a Daniel Defoe (novamente entra em cena a estratégia da supressão simbólica, que remete à reescritura da identidade), para que este 
escreva a história que ela, sozinha, não é capaz de escrever, porque não possui a técnica para tal. Todavia, quando expõe sua intenção em contar a história do período em que viveu na ilha, ao lado de Cruso e Friday, estabelece-se um conflito, pois Foe afirma que sua história, contada apenas baseando-se na verdade, não vai ser interessante nem, por conseguinte, vendável.

Já que não é escritora, vê-se impotente e dependente, porém resiste aos argumentos de Foe, que tenta a todo o momento corromper a integridade de seu relato. A partir disso, Susan passa a refletir sobre o ato de escrever, questionando-se, deste modo, se é possível criar um relato que esteja integralmente comprometido com a "verdade", assim como levantando a interrogação a respeito de se há uma maneira de escrever uma narrativa ficcional que seja a expressão fiel desta, uma vez que todo autor, com seu engenho, lança mão de estratégias para tornar o discurso mais atrativo ao público leitor, de acordo com seus interesses. Em suma: “O escritor Foe tenta colonizar a narrativa de Barton.” (BONNICI, 2000, p. 121).

Esta enunciação metadiscursiva põe à prova a história narrada pelo centro e evidencia a existência de outros pontos de vista. Ao tentar escrever sua história, Susan Barton encontra resistência no escritor Foe, de forma que não consegue encontrar um meio que lhe assegure que sua escrita seja expressão da verdade que quer narrar. Essa problemática traz à luz a pergunta: de que maneira seria possível povos subjugados pela escravidão, ou pela colonização, ou ambos, encontrarem uma maneira alternativa ou legítima de expressar suas realidades ou seu ponto de vista histórico?

Ao trazer uma mulher europeia como narradora, Coetzee sublinha a incompatibilidade cultural e discursiva entre povos hierarquicamente distintos, além de colocar em destaque a questão relativa aos gêneros masculino e feminino. Susan se depara com a impossibilidade de contar uma história que não é sua, e se dá conta de que nunca saberá toda a verdade, pois seu desejo "esbarra na percepção de quão pouco conhece realmente a história que quer narrar, e parece reduzir-se ao silêncio quando considerada a impossibilidade de os reais detentores do conhecimento verbalizarem sua história." (SILVA, 2000, p. 234), afinal, Friday não pode contar sua história porque, ao ter sua língua cortada, perdeu o poder da palavra e ele é o único que poderia preencher as lacunas deixadas por Cruso.

Somado a isso, há em Susan uma incapacidade em perceber a linguagem com a qual Friday se manifesta: "All my efforts to bring Friday to speech, or to bring speech to Friday, have failed,' I Said. 'He utters himself only in music and dancing." (COETZEE, 1987, p. 142). As várias manifestações linguísticas de Friday não são percebidas por Susan, que 
acredita ser a escrita a única forma possível de expressão: “Susan jamais poderá ir além da maneira tradicional européia de contar a história, isto é, exclusivamente através do discurso, e ele não pode imaginar que Friday o faça diferentemente". (BONNICI, 2000, p. 111)

Isso revela, segundo Bonnici (2000), o fracasso da escrita branca em tentar representar o discurso do negro. É inútil ao branco tentar, apesar de todos os esforços, falar em nome do negro, pelo simples fato de que já tem uma imagem pré-concebida do outro. Isso significa que a experiência branca jamais conseguirá compreender a negra em sua totalidade simplesmente porque não é sua. Sua tentativa em representá-la, aproxima-se da realidade que ficou perdida no tempo histórico e pode, sim, levar à reflexão, mas nunca alcançará os fatos plenamente. Nesse sentido, Friday vem a representar a problemática do outro, neste caso, um nativo que não pode falar, pois teve sua língua cortada. Isso o torna totalmente incapaz de ser um sujeito da própria história, ficando "indefeso contra o poder escravizante da palavra." (SILVA, 2000, p. 243).

Julga-se necessário acrescentar que a língua cortada abre a perspectiva de uma leitura sobre a alteridade tão presente no discurso pós-colonial. A "mutilação torna-se simbólica da estratégia do colonizador para fazê-lo perder sua identidade e sua caracterização fixa. Um personagem mutante facilmente poderia ser posto na alteridade e dominado". (BONNICI, 2000, p. 138). Se o colonizado não puder se expressar, fica muito mais fácil imprimir a cultura e seu discurso europeu ao colonizado. Dessa maneira, Silva (2000, p.242) entende que a história de Friday se apresenta como uma lacuna na narrativa, pois para a história do nativo restam somente hipóteses e suposições, enfim, um "vazio narrativo" cuja informação é ocultada pela mediação autodiegética de Crusoé, em Robinson Crusoé e de Susan Barton, em Foe. Essa exclusão, fruto da diferenciação com que o europeu trata os demais povos, acaba fabricando o outro, conforme nos aponta Bonnici (2000, p.82), o qual sublinha que essa atitude "parece simbolizar uma política mais nítida e mais demolidora que seria implementada nas relações metrópole-colônia no início do império britânico". (BONNICI, 2000, p. 82). Contudo, é importante destacar em relação ao processo de colonização a perspectiva de que, para além da aculturação impositiva, há um movimento de trocas culturais nesse choque entre povos, de tal forma que o dominador também sai transformado pelo contato com o dominado, como propõem algumas teorias contemporâneas como as da transculturação e do hibridismo cultural.

A estada de Crusoé no Brasil, o tráfico de escravos negros e o período na ilha e sua convivência "pacífica" com Sexta-feira, no romance de Defoe, podem, segundo Bonnici 
(2000, p.80) ilustrar perfeitamente o problema do encontro com o outro. Mesmo que o texto traga essa situação de forma velada, uma análise mais apurada revela o tipo de relação predominante no texto ou a voz dominante controlando o tom da narrativa. No Brasil, é nítida a relação sem exclusão ou hierarquia estabelecida entre Crusoé e os portugueses, bem como entre ele e a classe dominante brasileira: "Da narrativa depara-se que o relacionamento entre Crusoé e os europeus não revela nenhum discurso dominante, nenhum processo de exclusão ou falta de reciprocidade.” (BONNICI, 2000, p. 81). Há uma relação já estabelecida entre ele e os portugueses, ou seja, sua prosperidade no Brasil se deve à ajuda de portugueses e brasileiros, senhores de engenho ou fazendeiros, para os quais se propõe a buscar escravos na África, em troca de objetos sem ou de pouco valor.

Neste ponto, percebe-se fortemente a noção europeia de hierarquia. De acordo com a lógica eurocêntrica colonial, a escravidão não é um problema social, dado que os escravos são apenas mão de obra necessária à manutenção do sistema escravagista que move a dinâmica colonialista, sempre objetivando os lucros. Do mesmo modo, o texto de Defoe não põe em questão a moralidade dos atos cometidos, pois em nenhum momento se discute o contrabando de negros africanos que Crusoé se propõe a fazer, principal motivo que o faz embarcar em um navio e se lançar ao mar novamente, apesar de já ser ciente dos perigos, o que o faz ir parar nas ilhas do Caribe, que viria a ser, involuntariamente, sua residência algumas páginas à frente. Assim, escravizar negros africanos em troca de "quinquilharias" (objetos de pouco valor para os europeus) em nenhum momento é atitude punida ou questionada no texto: "Segundo a ética da qual está imbuída toda a narrativa, ela não abrange o outro, ou seja, deixa intocável a questão da moralidade do comércio em seres humanos”. (BONNICI, 2000, p. 82)

Outro episódio vem corroborar a ideia de hierarquização e subjugação de que o discurso europeu está imbuído. No romance do século XVIII, no momento em que Crusoé encontra Sexta-feira na ilha, após 25 anos de vida solitária, Bonnici (2000, p. 84) comenta que a autodiegese reforça a ideia de superioridade através da relação soberano-súdito que se estabelece entre Crusoé e o indígena, ratificando o processo de fabricação do outro, uma vez que o submete ao seu comando, ensinando-lhe apenas as palavras necessárias para que possa haver um mínimo de comunicação, como também mostra o começo da modelagem do indígena ao gosto europeu: "Crusoé imediatamente dispõe-se a imbuir sistematicamente o índio de costumes europeus, sem uma avaliação crítica do indígena como sujeito.” (BONNICI, 2000, p. 84). O protagonista ensina ao indígena sua língua e o ensina a chamá-lo "amo", reforçando a dicotomia: soberano X súdito. 
Uma questão muito relevante está presente no cerne de ambas as obras: tanto Defoe quanto Coetzee, por meio do gênero, discutem sua realidade e, mais especificamente, suas perspectivas quanto à problemática da colonização. Porém, há que se notar que enquanto o narrador de Robinson Crusoé revela fortes aspectos colonialistas, Bonnici (2000) comenta em seu estudo que, em Foe, Susan Barton questiona as atitudes de dominação e conquista que tentam ser impostas na ilha por Cruso. Ao reescrever o relato de Defoe, Coetzee põe em evidência a relação de dominação existente na empresa colonizadora que moveu em grande parte a aventura das grandes navegações modernas, porém, neste caso, o faz com um enfoque pós-colonial, no qual a perspectiva do povo colonizado é destacada.

Dessa maneira, insere-se no texto a desconstrução do que, em Robinson Crusoé, aparecia camuflado e "natural", legitimando-se o discurso do dominador. Quando Susan Barton interpela Cruso a respeito do silêncio de Friday, chama a atenção para uma lacuna deixada no clássico: “How many words of English does Friday know?' I asked. 'As many as he needs,' replied Cruso. 'This is not England, we have no need for a great stock of words."' (COETZEE, 1987, p. 21), ao que Susan replica: "What benefit is there in a life of silence?" (COETZEE, 1987, p. 22).

Esse embate ficcional reproduz a questão da alteridade em Robinson Crusoé, criando um simulacro que revela a posição em que se colocam os narradores em cada um dos textos. No romance canônico do século XVIII, Bonnici (2000, p. 80-81) mostra que a conduta do personagem acaba por evidenciar o problema do outro, apesar de o autor procurar escondê-lo, e as lacunas deixadas na narração autodiegética impelem a narrativa a dar pistas do tipo de relação excludente entre europeus e indígenas, sublinhando os contrastes presentes na alteridade: "Este hiato entre o sujeito e o objeto, o território da incerteza, é aproveitado pelo autor pós-colonial para reconstruir seus personagens pós-coloniais. O hibridismo pós-colonial com sua subversão da autoridade e a implosão do centro imperial constrói o novo sujeito póscolonial." (BONNICI, 1998, p. 15).

Característica das sociedades pós-coloniais, Bonnici (1998) nos aponta que a relação entre os sujeitos estabelece uma hierarquia "em que o oprimido é fixado pela superioridade moral do dominador." (BONNICI, 1998, p. 14). Nesse sentido, Coetzee se aproveita dos "buracos narrativos" deixados por Defoe, no século XVIII, para subverter o cânone em consonância com o ideário do discurso pós-colonial: “A língua cortada do personagem Friday no romance Foe (1986), de J. M. Coetzee, é o símbolo do colonizado mudo por ato voluntário do colonizador.” (BONNICI, 1998, p. 14). 
Thomas Bonnici se aprofunda na discussão analisando que estratégias, então, podem ser utilizadas para recuperar a voz do sujeito colonial dominado e da mulher subalterna, ou seja, como se pode reescrever a história do colonizado na história. O que geralmente se vê é a história de colonizadores e colonizados contadas pela metodologia do gênero "narrativas de viagem", em que o narrador é tipicamente um homem, o qual narra sua trajetória de desbravamento, conquistas ou descobertas. Quase não se nota a presença da mulher, e o nativo serve apenas como objeto para a narração. Ao dar voz a uma personagem do sexo feminino, Susan Barton, o autor pós-colonial simbolicamente evidencia a nova perspectiva com que mira o passado, buscando dar voz àqueles outrora excluídos do processo, ou melhor, inseridos nele de forma marginalizada. Isso quer dizer que, além de representar povos subjugados pelo poder imperialista, Coetzee ainda chama a atenção para o patriarcalismo que reinava no período em que, além do nativo subjugado, a mulher também ocupava um lugar de subserviência na sociedade. O estilo da narração em Coetzee expõe, portanto, duas formas de dominação: de um lado, de um povo sobre os demais povos, e de outro, do homem em relação à mulher. Nesse sentido, Susan Barton pode ser considerada um signo híbrido representativo dos dois temas.

A voz de Susan representa uma mudança de postura e assim, promove uma reestruturação do gênero em questão, quando não aceita passivamente a tentativa de dominação que Cruso tenta lhe impor: "Barton desfia-lhe as ordens, questiona-lhe o domínio [...]." (SILVA, 2000, p. 229), desconstruindo a figura do colonizado passivo e do dominador soberano. Susan se nega a obedecer às regras preestabelecidas por Cruso, rebelando-se contra qualquer tentativa de imposição. Thomas Bonnici nos diz que: "como sujeito de sua história, a narradora reage contra as conquistas e a dominação da ilha por Cruso. Embora a ilha tenha sido inutilmente submetida (a terra trabalhada e posta em terraços) por Cruso, ela não admite ser submissa a semelhantes restrições.” (BONNICI, 2000, p. 94). Susan Barton, em Foe, acaba de chegar de uma colônia, o Brasil, por isso aparece como a outra parte, ou seja, ela se torna figura representativa dos povos colonizados. Nesse sentido, cabe a ela o papel de não se permitir colonizar pelo homem europeu. As tentativas de Cruso em dominar Susan são autoritárias, porém, inócuas: "While you live under my roof you will do as I instruct!" (COETZEE, 1987, p. 20), ao que Susan, com ímpeto e ousadia dá a replica: "I am a castaway, not a prisoner." (COETZEE, 1987, p. 20).

Por outro lado, conforme afirma Fernando de Lima Paulo (2003), em alguns momentos a narradora entra em contradição com seu próprio discurso, quando, no desenrolar 
do texto "[...] parece recorrer às tradicionais narrativas de exploradores." (PAULO, 2003, p. 29). Ao criticar o modo de vida de seu anfitrião, Susan parece remeter à postura imperialista que ela tanto critica, quando, ao se deparar com as diferenças, seu tratamento se guia na alteridade, ou seja, ela mantém uma distância de identificação com Cruso e, de forma diferenciada, com Friday.

Com efeito, para que se possa parodiar o clássico, o autor sul-africano necessita lançar mão dos artifícios próprios da literatura tradicional de viajantes, para dessa forma atingir o tom crítico buscado por ele e denunciar o tom imperial dos narradores tradicionais da literatura de viagem. Nesse sentido, a narradora de Foe faz descrições da ilha, bem ao gosto eurocêntrico do típico narrador de literatura de viagem, apresentando certa "aversão à diferença, às coisas a que o explorador não está habituado e sua tendência natural de vê-las como sujas ou impróprias" (PAULO, 2003, p. 29). Ela também comenta o modo de vida dos habitantes e age como uma verdadeira europeia diante do diferente: "In the hut Cruso had a narrow bed, which was all his furniture. The bare earth formed the floor." (COETZEE, 1987, p. 9). Diante disto, é possível perceber o quão incrustado de discurso colonial está o discurso que tenta ser subversivo. Da mesma forma, o subserviente Friday se deixa manipular pela ideologia dominante e perde sua verdadeira identidade, ou melhor, deixa que ela se confunda com o que lhe foi incutido no pensamento. Então, como seria possível narrar a "verdade histórica" pelo discurso ideologicamente minado pelas distorções da fala do colonizador?

Thomas Bonnici nos diz que tanto o nativo quanto a figura feminina estão em posição de subalternos diante do poder dominante, portanto, não podem falar. Isso não significa, segundo o autor, "que não possam organizar sua resistência ou que devam fazê-la numa voz ou linguagem dominante para que possam ser ouvidos" (BONNICI, 2000, p. 136). Em seu texto, Bonnici comenta que a resistência do subalterno existe, porém não há como separá-la totalmente do discurso da classe dominante, e nem sempre essa separação é conveniente para que possa ser ouvido. Isso se dá "porque o poder colonial é tão generalizado e tão devastador que ele reescreveu o sistema intelectual, legal e cultural do nativo". (BONNICI, 2000, p. 136)

Da mesma forma, se Robinson Crusoé "promove distorções e o silenciamento de outras verdades" (PAULO, 2003, p. 31), Susan insiste em produzir um texto que não exclua os "fatos". Ela quer narrar a história de Friday e sua língua mutilada, porém esbarra na impossibilidade de sucesso, uma vez que o único que a pode narrar é o próprio Friday. Este insurge na narrativa como o símbolo desse silêncio, uma sombra que impõe sua presença e 
figura como um mistério insolúvel. Ele tem guardado consigo uma verdade que jamais será contada, seguramente porque, sem sua língua, restam-lhe, de substancial, apenas o corpo e a linguagem que lhe é peculiar.

Para Susan Barton, que o relega à posição de alteridade, o estranhamento com que encara a natureza de Friday, considerando-o "uma 'criatura sombria', a quem deve ser dada a atenção semelhante àquela dada a um "escravo"” (BONNICI, 2000, p. 138) traz para a narrativa a problemática do autor pós-colonial, que busca resgatar a identidade de um povo subjugado e submetido a um processo educacional colonizador. Contudo, suas indagações mostram que um povo silenciado deixa escapar entre os dedos do tempo a memória de suas verdades mais profundas, e, aqueles que vierem depois, jamais saberão ao certo o que formou sua essência:

\footnotetext{
I say he is a cannibal and he becomes a cannibal; I say he is a laundryman and he becomes a laundryman. What is the truth of Friday? You will respond: he is neither cannibal nor laundryman, these are mere names, they do not touch his essence, he is a substantial body, he is himself, Friday is Friday. But that is not so. No matter what he is to himself (is he anything to himself? - how can he tell us?), what he is to the world is what I make of him. (COETZEE, 1987, p. 121-22)
}

Há que se notar, contudo, que a informação a respeito da capacidade do nativo de exercer sua vontade é trazida ao conhecimento do leitor através da narração de Susan, a qual insistentemente o restringe à condição de silêncio. Desta maneira, seja silenciando ou sendo silenciado, Friday leva consigo um mutismo cheio de significados, mas que somente poderão significar de fato se ele verbalizá-los, ou seja, se ele tiver "voz". Isto mostra que há outras possibilidades de manifestação de vontade, mas que são tolhidas pelo poder esmagador da palavra imposta.

O texto de Coetzee vem, portanto, não apenas questionar a problemática dos povos colonizados, mas também, discutir a possibilidade de fazê-lo. Uma vez inserido em um contexto histórico e social diverso, Coetzee coloca em evidência os obstáculos encontrados ao se tentar demonstrar a essência de algo que não lhe pertence, ou melhor, as agruras de falar pelo outro sem sê-lo.

\section{À guisa de conclusão}

A atitude do autor pós-modernista implica em uma nova forma de ver o passado ou encarar o momento presente, subvertendo os axiomas estabelecidos pela literatura clássica. Do mesmo modo, questionar anos e anos de imperialismo manifesto em séculos de pensamento ocidental, procurando mostrar a outra face de um processo colonialista tido por 
acabado, implica em dizer que uma literatura pós-colonialista consiste em uma descolonização do pensamento ocidental. Tarefa difícil, uma vez que, não se pode mensurar até que ponto o leitor contemporâneo está preparado para essa mudança.

O desenvolvimento deste trabalho mostra que a literatura pós-colonial ainda encontra muitas barreiras em face da forte presença do pensamento colonial, bem como de sua postura de superioridade, que ainda permanece incutida no pensamento ocidental. Por outro lado, tal literatura oferece a oportunidade de resposta pós-colonial ao resgatar textos e analisá-los sob uma nova perspectiva. Conforme já citado nos capítulos acima, não é intenção dos autores pós-coloniais estabelecer uma nova ordem hierárquica, mas sim promover a reflexão a respeito da relação de dominação e quiçá contribuir para que se recupere a voz dos povos colonizados, da literatura colonizada.

Como o romance de Coetzee revela, a ficção consegue chegar a lugares que talvez a história não alcance, não porque seja mal intencionada, mas simplesmente pelo fato de que é seu compromisso narrar fatos e não tecer reflexões literárias sobre eles. Desse modo, o romance Foe faz surgir a reflexão a respeito da colonização, tanto política, quanto cultural, econômica e também literária.

Ao final do texto, Coetzee reproduz uma viagem simbólica às profundezas do ser, significando uma viagem às profundezas da história, na tentativa de ecoar a voz marginalizada dos povos colonizados. Por este prisma, a literatura pós-colonial coloca em evidência a trajetória conflituosa dos povos subjugados, e o próprio fato de o autor ser um escritor branco com ascendência europeia traz à tona a problemática do discurso da alteridade. Contudo, entende-se que a literatura coloca em movimento exatamente esse deslocamento das subjetividades, permitindo que um sujeito escritor como Coetzee, a partir de sua experiência cultural, imagine-se no papel (e na pele) de outrem, do negro, da mulher, e possibilite, no espaço simbólico da ficção, revelar outros pontos de vista, a saber, do sujeito à margem, como possíveis respostas pós-coloniais ao discurso colonizador.

\section{Referências}

BONNICI, Thomas. O pós-colonialismo e a literatura: Estratégias de Leitura. Maringá: Eduem, 2000. $\overline{07-23,1998 .}$

Introdução ao estudo das literaturas pós-coloniais. In: Mimesis. Bauru, v. 19, n. 1, p.

BOJIĆ, Majda. Crítica da dimensão política da representação no romance pós-moderno e sua cumplicidade: considerações sobre Foe, de Coetzee. In: Congresso Internacional da 
ABRALIC, 11, 2008, São Paulo. Anais. São Paulo: USP, 2008. Disponível em: $<$ http://www.abralic.org.br/anais/cong2008/AnaisOnline/simposios/pdf/056/MAJDA BOJIC. pdf $>$. Acesso em: 15 jun. 2012.

COETZEE, John M. Foe. New York: Penguin Books, 1987.

COSTA LIMA, Luiz. O controle do imaginário e a afirmação do romance. São Paulo: Cia das Letras, 2009.

DEFOE, Daniel. As aventuras de Robinson Crusoé. Tradução de Albino Poli Jr. Porto Alegre: L\&PM, 2010.

ESTEVES, Antonio R; ZANOTO, Sérgio A. (Orgs.). Literaturas de viagem - viagens na literatura. In: Literaturas de viagem - viagens na literatura. Assis: Triunfal Gráfica e Editora, 2010 .

HANCIAU, Núbia J. Confluências entre os discursos histórico e ficcional. Cadernos Literários. Rio Grande: FURG, 2001, v. 5, n. 5, p.73-81. Disponível em: http://www.hanciau.net/arquivos/CADERNOSLITERARIOS2001-CONFLUENCIAS...pdf.

Acesso em: 11 jun. 2013.

HUTCHEON, Linda. Poética do Pós-Modernismo. Rio de Janeiro: Imago, 1991.

NITRINI, S. Literatura Comparada: História, Teoria e Crítica. São Paulo: Edusp, 2000.

PAULO, Fernando de L. O tema da verdade em Foe, de J. M. Coetzee. Em Tese. Belo Horizonte, v.7, p. 27-34, dez. 2003. Disponível em: http://www.letras.ufmg.br/poslit/08 publicacoes pgs/Em\%20Tese $\% 2007 / 03$-FernandoLima.pdf. Acesso em: 29 ago. 2011.

SILVA, Denise A. Silêncio e resistência em Foe, de J. M. Coetzee. In: PETERSON, Michel (Org.). As armas do texto. A literatura e a resistência da literatura. Porto Alegre: Sagra Luzzato, 2000.

WATT, Ian. A ascensão do romance: estudos sobre Defoe, Richardson e Fielding. Tradução: Hildegard Feist. São Paulo: Companhia das Letras, 1990.

[Recebido em janeiro de 2015 e aceito para publicação em junho de 2015]

\section{Robinson Crusoe in Foe: Coetzee reads Defoe through post-colonial lens}

Abstract: This study consists of the analysis of two important novels which represent the travel writing. They are Robinson Crusoe (1719) and Foe (1986), whose authors, respectively Daniel Defoe, in the eighteenth century, and John Maxwell Coetzee, in the twentieth century, also dialogue in writing through the Shakespeare language. Building on these intersections, we seek to establish, through literary comparativism, the textual and historical relations between their works. The novel Foe appears as a contemporary reinterpretation of the travel narrative genre which had already been developed in Robinson Crusoe, an earlier novel of this thematic category. Coetzee takes over the classic work establishing reflections concerning the colonial context in which Defoe wrote his work. Thus Coetzee takes a new look at the theme 
under the focus of the post-colonialism approach. This perspective reflects the way of writing the text, so the genre, reflection of the image of a period, ends up being rebuilt, according to the post-modern perspective.

Keywords: Robinson Crusoe. Foe. Colonialism. Post-colonialism. Post-modernism.

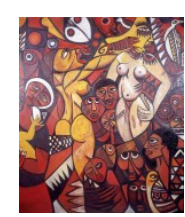

